\title{
PENGARUH TEMPERATUR DAN KELEMBABAN TERHADAP TINGKAT KERUSAKAN DAUN JABON (Anthocephalus cadamba) OLEH Arthrochista hilaralis
}

\author{
The Effect of Temperature and Humidity to the Severity Level Caused by \\ Arthrochista hilaralis in Jabon (Anthocephalus cadamba) \\ Avry Pribadi ${ }^{1)}$ dan/and Illa Anggraeni ${ }^{2)}$ \\ ${ }^{1)}$ Balai Penelitian Hutan Penghasil Serat, Kuok \\ Jl. Raya Bangkinang, Kuok Km. 9 Bangkinang, Kampar, Riau 28294 \\ Telp. (0762) 7000121, Fax. (0762) 7000122 \\ ${ }^{2)}$ Pusat Litbang Peningkatan Produktivitas Peningkatan Hutan, Bogor \\ Jl. Gunung Batu No. 5 Bogor, Telp. (0251) 8631238, Fax. (0251) 7520005 \\ Naskah masuk : 17 Mei 2010; Naskah diterima : 23 Desember 2010
}

\begin{abstract}
Arthrochista hilaralis is the defoliator pest that caused foliar damage (severity level) up to $97,88 \%$ on jabon plantation at HTI Baserah sector and 67,80\% at Pantai Cermin community forest. The difference of severity level between these location is probably caused by temperature and humidity. The aim of this research was to find the role of temperature and humidity to foliar damage caused by A. hilaralis. Systematic sampling was used to determined the observation plot. There were 5 plots and every plot contain 100 trees. Observation was done to foliar severity level and abiotic factor (temperature and humidity). The results show that the temperature has negative correlation $\left(-0,288^{* *}\right)$ and humidity has positive correlation (0,303**) to severity level at HTI Baserah but at HR Pantai Cermin showed that temperature has positive correlation $\left(0,169^{* *}\right)$ and humidity has negative correlation $\left(-0,187^{* *}\right)$. The regression equation between severity level to temperature and humidity at HTI Baserah sector was $Y=$ $4,418-0,015 X 1+0,014 X 2(R=0,305)$ and $Y=4,961 \quad 0,029 X 1 \quad 0,004 X 2(R=0,187)$ at HR Pantai Cermin.
\end{abstract}

Keyword: Arthrochista hilaralis, correlation, humidity, regression, temperature

\begin{abstract}
ABSTRAK
Arthrochista hilaralis merupakan hama defoliator yang menyebabkan tingkat kerusakan sampai 97,88\% pada tanaman jabon di Hutan Tanaman Industri (HTI) sektor Baserah dan 67,80\% di Hutan Rakyat (HR) Pantai Cermin. Perbedaan tingkat kerusakan ini diduga berkaitan dengan pengaruh kelembaban dan temperatur. Tujuan dari penelitian ini adalah untuk mengetahui hubungan antara tingkat kerusakan daun akibat serangan $A$. hilaralis dengan temperatur dan kelembaban. Penelitian dilakukan di dua lokasi, yaitu areal HTI sektor Baserah, Kabupaten Kuansing dan areal HR Pantai Cermin, Kabupaten Kampar, Riau. Pada masing-masing lokasi dibangun 5 plot pengamatan, masing-masing plot terdiri atas 100 pohon. Plot ditempatkan secara sistematik mengikuti metode kudratik. Parameter yang diukur adalah tingkat kerusakan daun oleh A. hilaralis, temperatur dan kelembaban lingkungan di sekitar pohon. Hasil menunjukkan bahwa di HTI sektor Baserah temperatur berkorelasi negatif $\left(-0,288^{* *}\right)$ dan kelembaban berkorelasi positif $(0,303 * *)$ terhadap tingkat kerusakan. Pada HR Pantai Cermin, temperatur berkorelasi positif $\left(0,169^{* *}\right)$ dan kelembaban berkorelasi negatif $\left(-0,187^{* *}\right)$ terhadap tingkat kerusakan daun akibat A. hilaralis. Persamaan linear regresi antara tingkat kerusakan dengan temperatur serta kelembaban untuk lokasi HTI sektor Baserah adalah $\mathrm{Y}=4,4180,015 \mathrm{X} 1+0,014 \mathrm{X} 2(\mathrm{R}=0,305)$ dan pada HR Pantai Cermin adalah $\mathrm{Y}=4,961-0,029 \mathrm{X} 1-0,004 \mathrm{X} 2(\mathrm{R}=0,187)$.
\end{abstract}

Kata kunci: Arthrochista hilaralis, korelasi, kelembaban, regresi, temperatur 


\section{PENDAHULUAN}

Perkembangan serangga hama dipengaruhi oleh beberapa faktor biotik dan abiotik. Contoh faktor biotik adalah keberadaan predator dan tingkat fekunditas sedangkan faktor abiotik terdiri atas faktor lingkungan seperti temperatur, kelembaban, $\mathrm{pH}$, dan curah hujan. Menurut Petzoldt and Seaman (2010), sebagai hewan yang berdarah dingin, serangga memiliki temperatur tubuh hampir sama dengan temperatur lingkungan, sehingga temperatur memiliki peranan penting yang akan mempengaruhi tingkah laku, distribusi, pertumbuhan, kelangsungan hidup, dan reproduksi. Misalnya adalah lalat Stomoxys calcitrans (Diptera) yang populasinya menurun jika temperatur lingkungan menurun (Vazquez et al., 2004). Selain itu, faktor abiotik juga berpengaruh terhadap turgorisitas dan fisiologi tanaman yang akhirnya akan mempengaruhi ketahanan tanaman terhadap hama. Temperatur lingkungan berpengaruh terhadap sintesis senyawa metabolit sekunder seperti alkaloid dan flavonoid yang mempengaruhi ketahanan tumbuhan terhadap hama dan penyakit (Wiyono, 2007).
Arthochista hilaralis merupakan hama defoliator yang dapat menimbulkan tingkat kerusakan tinggi pada tanaman jabon. A. hilaralis termasuk ke dalam ordo Lepidoptera famili Pyralidae. Serangga ini merupakan jenis ngengat (moth) yang aktif pada malam hari (Gambar 1). Pada fase larva, hama ini menyerang daun muda dan akan memakannya sampai hanya menyisakan tulang daun. Pengamatan pada plot penelitian di PT. RAPP sektor Baserah menunjukkan bahwa tingkat kerusakan akibat serangan A. hilaralis mencapai 97,80\%, sedangkan pada lahan Hutan Rakyat (HR) Pantai Cermin, tingkat kerusakannya lebih rendah $(67,80 \%)$. Perbedaan tingkat kerusakan ini diduga berkorelasi dengan variasi temperatur dan kelembaban lingkungan.

Penelitian ini bertujuan untuk mengetahui pengaruh kelembaban dan temperatur terhadap tingkat kerusakan yang disebabkan oleh $A$. hilaralis. Hasil penelitian ini diharapkan dapat dijadikan sebagai informasi dasar dalam pengendalian serangan $A$. hilaralis secara terpadu.

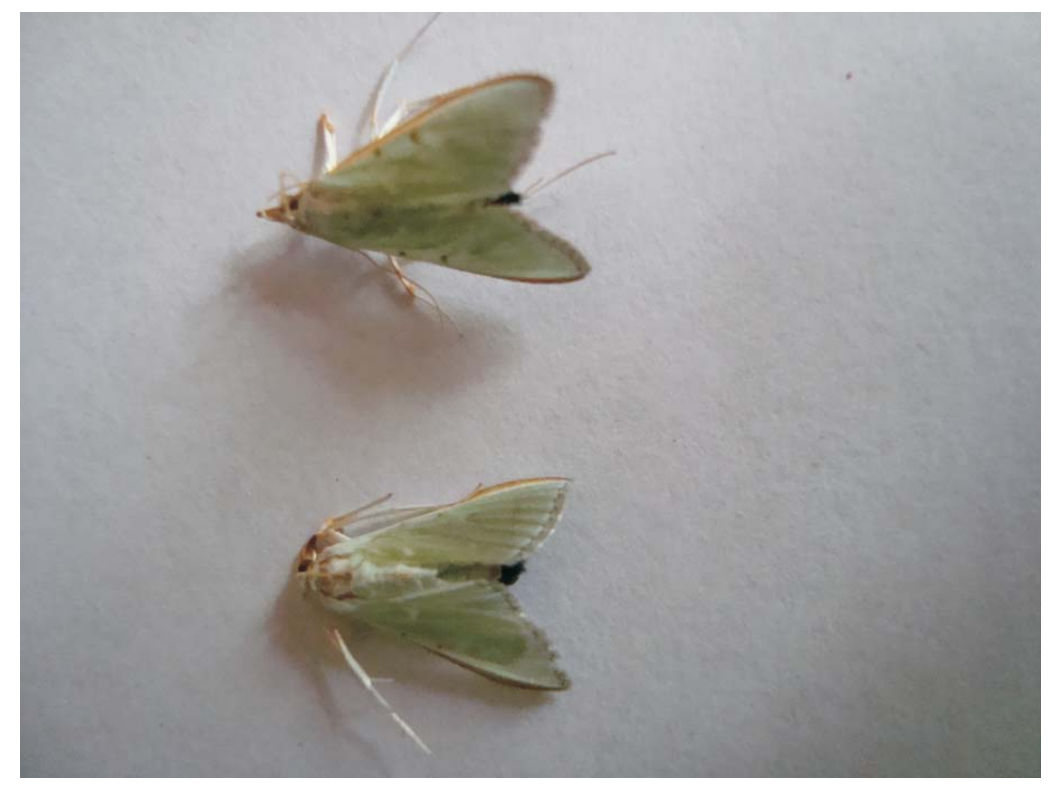

Gambar (Figure)1. Arthochista hilaralis dewasa (Image Arthochista hilaralis) 


\section{BAHAN DAN METODE}

\section{A. Lokasi dan waktu penelitian}

Penelitian dilaksanakan di dua lokasi, yaitu kawasan konsesi HTI pulp dan kertas milik PT. Riau Andalas Pulp \& Paper (RAPP) sektor Baserah Kabupaten Kuansing dan kawasan Hutan Rakyat (HR) Pantai Cermin Kabupaten Kampar, Riau. Penelitian ini berlangsung selama 8 bulan mulai bulan Januari 2009 sampai bulan September 2009.

\section{B. Rancangan penelitian}

Plot pengamatan untuk masing-masing lokasi ditentukan dengan metode systematic sampling. Pada masing-masing lokasi dibangun 5 plot pengamatan dan tiap plot terdiri atas 100 pohon. Plot pengamatan tiap lokasi dibuat dengan metode bujur sangkar yaitu pada pojok dan tengah lokasi. Parameter yang diamati adalah tingkat kerusakan daun oleh A. hilaralis, kelembaban dan temperatur setiap lingkungan pohon dilakukan dengan menggunakan thermohigrometer. Waktu pengambilan data dilakukan pada pagi, siang, dan sore hari.

Tingkat kerusakan akibat serangan $A$. hilaralis didekati dengan skoring yang digunakan Kilmaskossu dan Nerokouw (1993). Kerusakan daun akibat serangan $A$. hilaralis ditentukan dengan mengamati dan menghitung jumlah daun yang rusak setiap pohon kemudian dilakukan penilaian dengan menggunakan teknik skoring sebagai berikut:
1 : Sangat ringan (serangan $1 \%-20 \%$ ),

2 : Ringan (serangan $21 \%-40 \%$ ),

3 : Sedang (serangan $41 \%-60 \%$ ),

4 : Berat (serangan $61 \%-80 \%$ ),

5 : Sangat berat (serangan $81 \%-100 \%$ ).

\section{Analisa data}

Analisa data korelasi dan regresi dilakukan menggunakan SPSS 14 untuk melihat hubungan antara tingkat kerusakan daun oleh $A$. hilaralis dengan temperatur dan kelembaban.

\section{HASIL DAN PEMBAHASAN}

\section{A. Korelasi antara Temperatur dan Kelembaban dengan Tingkat Kerusakan Daun oleh A. hilaralis}

Nilai korelasi antara kelembaban dan temperatur lingkungan dengan tingkat kerusakan oleh serangan $A$. hilaralis pada HR Pantai Cermin disajikan pada Tabel 1. Berdasarkan Tabel 1, diperoleh bahwa kelembaban pada HR Pantai Cermin berkorelasi negatif terhadap tingkat kerusakan akibat serangan $A$. Hilaralis $(-0,187)$ dan menunjukkan korelasi nyata pada taraf 1\%. Hal ini berarti penurunan kelembaban akan diikuti oleh peningkatan tingkat kerusakan oleh A. hilaralis. Sebaliknya, kenaikan kelembaban akan diikuti oleh penurunan tingkat kerusakan oleh $A$. hilaralis.

Tabel(Table) 1. Nilai koefisien korelasi temperatur dan kelembaban dengan tingkat kerusakan oleh A. hilaralis pada HR Pantai Cermin (Coeffisient Correlation between temperature and humidity to severity level caused by A. hilaralis at community forest at Pantai Cermin)

\begin{tabular}{|l|c|c|c|}
\hline & $\begin{array}{c}\text { Tingkat kerusakan } \\
\text { (Severity level) }\end{array}$ & $\begin{array}{c}\text { Kelembaban } \\
\text { (Humidity) }\end{array}$ & $\begin{array}{c}\text { Temperatur } \\
\text { (Temperature) }\end{array}$ \\
\hline $\begin{array}{l}\text { Tingkat kerusakan } \\
\text { (Severity level) }\end{array}$ & $-0,187(* *)$ & $0,169(* *)$ \\
\hline $\begin{array}{l}\text { Kelembaban } \\
\text { (Humidity) }\end{array}$ & $-0,187(* *)$ & & $-0,914(* *)$ \\
\hline $\begin{array}{l}\text { Temperatur } \\
\text { (Temperature) }\end{array}$ & $0,169(* *)$ & $-0,914(* *)$ & \\
\hline
\end{tabular}

Keterangan (Remarks): * Korelasi signifikan pada level 0,05 (Significant correlation at 0,05 level)

** Korelasi signifikan pada level 0,01 (Significant correlation at 0,01 level) 
Whiting et al. (2010) menyatakan apabila tanaman berada dalam kondisi lingkungan yang berkelembaban rendah maka akan mudah terserang oleh hama dan penyakit. Hal ini diduga karena senyawa saponin yang terdapat pada berbagai jenis tumbuhan dan bersama-sama dengan metabolit sekunder lainnya (yang berperan sebagai pertahanan diri dari serangan serangga) akan mengalami penurunan kualitas dan kuantitas sehingga tumbuhan akan mudah terserang hama. Menurut Smith (1997), senyawa pertahanan tumbuhan seperti alkaloid, terpenoid, dan flavonoid bersifat menghambat pertumbuhan serangga hama dengan cara mengurangi nafsu makan hingga menimbulkan kematian. Selain itu, Kalshoven (1981) menyatakan bahwa tanaman yang sedang mengalami cekaman oleh lingkungan mudah terserang oleh hama dan penyakit.

Tingkat kerusakan oleh serangan $A$. hilaralis menunjukkan korelasi positif dengan temperatur lingkungan $(0,169)$ dan menunjukkan korelasi yang nyata pada taraf $1 \%$. Hal ini berarti temperatur berbanding lurus dengan tingkat kerusakan oleh $A$. hilaralis, sehingga peningkatan temperatur akan diikuti dengan meningkatnya kerusakan. Peningkatan temperatur akan meningkatkan metabolisme dari serangga sampai batas tertentu. Hal ini disebabkan karena hama termasuk hewan yang temperatur tubuhnya dipengaruhi oleh temperatur lingkungan (poikiloterm). Hewan poikiloterm membutuhkan panas dari lingkungan untuk memulai aktivitas metabolismenya dengan mengaktifkan enzim-enzim pencernaannya. Hal ini sesuai dengan hasil studi Horn (2010) yang menyatakan bahwa aktivitas enzim pada serangga akan meningkat dengan naiknya suhu sehingga intensitas makan mereka akan meningkat. Tetapi hal ini terjadi untuk periode yang singkat karena pada suhu tinggi enzim mengalami denaturasi dan pemanasan oleh suhu tinggi dalam waktu yang lama akan mengakibatkan kerusakan enzim. Selain itu menurut Petzoldt and Seaman (2010), peningkatan temperatur akan meningkatkan pertumbuhan serangga hama dan akan berdampak meningkatnya kerusakan yang diakibatkannya. Selain itu, Bale et al., (2002) menyatakan bahwa tingkat keragaman dan intensitas makan serangga hama akan meningkat jika temperatur lingkungan meningkat. Pertumbuhan serangga dapat dihubungkan dengan tingkat metabolisme serangga itu sendiri. Serangga yang termasuk dalam jenis poikiloterm membutuhkan panas dari lingkungan untuk memulai metabolismenya. Oleh sebab itu peningkatan temperatur lingkungan akan berdampak kepada metabolisme serangga yang kemudian akan meningkatkan kemampuan makannya yang kemudian akan berdampak pada pertumbuhan serangga itu sendiri.

Tabel(Table) 2. Nilai koefisien korelasi temperatur dan kelembaban dengan tingkat kerusakan oleh A. hilaralis pada HTI sektor Baserah (Coefficient correlation between temperature and humidity to severity level caused by A. hilaralis at HTI Baserah sector)

\begin{tabular}{|l|c|c|c|}
\hline & $\begin{array}{c}\text { Tingkat kerusakan } \\
\text { (Severity level) }\end{array}$ & $\begin{array}{c}\text { Kelembaban } \\
\text { (Humidity) }\end{array}$ & $\begin{array}{c}\text { Temperatur } \\
\text { (Temperature) }\end{array}$ \\
\hline $\begin{array}{l}\text { Tingkat kerusakan } \\
\text { (Severity level) }\end{array}$ & $0,303(* *)$ & $-0,288\left(^{* *}\right)$ \\
\hline $\begin{array}{l}\text { Kelembaban } \\
\text { (Humidity) }\end{array}$ & $0,303(* *)$ & $-0,898\left(^{* *}\right)$ \\
\hline $\begin{array}{l}\text { Temperatur } \\
\text { (Temperature) }\end{array}$ & $-0,288(* *)$ & $-0,898(* *)$ & \\
\hline
\end{tabular}

Keterangan (Remarks): * Korelasi signifikan pada level 0,05 (Significant correlation at 0,05 level)

** Korelasi signifikan pada level 0,01 (Significant correlation at 0,01 level) 
Pada HTI sektor Baserah diperoleh bahwa kelembaban berkorelasi positif terhadap tingkat kerusakan akibat serangan $A$. hilaralis $(0,303)$ dan menunjukkan korelasi yang nyata pada taraf $1 \%$. Hal ini berarti peningkatan kelembaban akan diikuti oleh meningkatnya kerusakan oleh $A$. hilaralis. Sebaliknya, penurunan kelembaban akan diikuti oleh menurunnya tingkat kerusakan oleh A. hilaralis.

Tabel(Table) 3. Rata-rata temperatur dan kelembaban pada 2 lokasi penelitian (Average of temperatur and humidity at 2 locations)

\begin{tabular}{|c|c|c|c|}
\hline \multicolumn{2}{|c|}{ HR Pantai Cermin } & \multicolumn{2}{|c|}{$\begin{array}{c}\text { HTI sektor Baserah } \\
\text { (HTI Baserah sector })\end{array}$} \\
\hline $\begin{array}{c}\text { Temperatur Cermin community forest }) \\
(\text { Temperature })\left({ }^{\circ} \mathrm{C}\right)\end{array}$ & $\begin{array}{c}\text { Kelembaban } \\
(\text { Humidity })(\% \mathrm{RH})\end{array}$ & $\begin{array}{c}\text { Temperatur } \\
(\text { Temperature })\left({ }^{\circ} \mathrm{C}\right)\end{array}$ & $\begin{array}{c}\text { Kelembaban } \\
\text { (Humidity })(\% \mathrm{RH})\end{array}$ \\
\hline 34,0 & 67,27 & 36,06 & 57,84 \\
\hline
\end{tabular}

Temperatur lingkungan menunjukkan korelasi negatif dengan tingkat kerusakan oleh serangan $A$. hilaralis $(-0,288)$ dan menunjukkan korelasi yang nyata pada taraf $1 \%$. Hal ini berarti temperatur berbanding terbalik dengan tingkat kerusakan oleh A. Hilaralis, sehingga peningkatan temperatur akan diikuti dengan menurunnya tingkat kerusakan oleh A. hilaralis. Jika melihat pada Tabel 3, rata-rata kelembaban HTI sektor Baserah $(57,84 \%)$ memiliki nilai lebih rendah dibandingkan pada HR Pantai Cermin $(67,27 \%)$. Diduga kelembaban yang rendah dan temperatur yang tinggi dapat mengakibatkan serangga hama dan tanaman itu sendiri mengalami dehidrasi. Menurut Salisbury dan Ross (1995), air sangat dibutuhkan dalam berbagai reaksi oleh tanaman, misalnya fotosintesa dan media dalam reaksi biokimia. Air yang hilang oleh transpirasi dapat menyebabkan tanaman kehilangan turgoritas sehingga mudah terserang hama.
Bagi sebagian besar serangga, kehilangan air akibat dehidrasi dapat berdampak pada menurunnya aktivitas metabolisme. Sehingga diduga metabolisme dari $A$. hilaralis akan berjalan lambat yang kemudian akan berdampak pada menurunnya tingkat kerusakan yang diakibatkannya. Menurut Awmack et al. (1997), pada temperatur tinggi beberapa serangga akan menjadi lebih rentan terhadap serangan predator dan parasit karena menjadi tidak responsif terhadap musuhnya tersebut, sehingga kemampuan makan menurun. Serangan serangga parasitoid terhadap serangga hama (Gambar 2).

Selain itu, menurut Child (2010) untuk kebanyakan serangga hama, temperatur diantara $15{ }^{\circ} \mathrm{C}$ sampai $35^{\circ} \mathrm{C}$ akan meningkatkan energi, sehingga serangga hama tersebut mampu meningkatkan kemampuan mobilitas, rata-rata kecepatan makannya, kemampuan bereproduksi, dan mengurangi tingkat mortalitasnya.

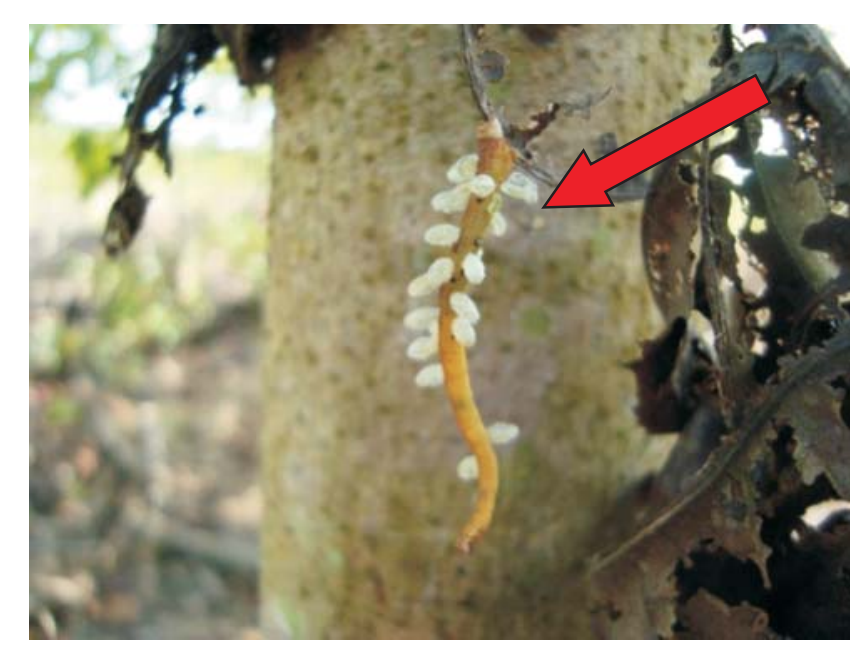

Gambar(Figure)2. Serangan serangga parasitoid pada serangga hama pada HTI sektor Baserah (Parasitoid attacks pest insect at HTI Baserah Sector) 


\section{B. Pengaruh Kelembaban dan Temperatur terhadap Tingkat Kerusakan oleh $A$. hilaralis}

Pengaruh antara kelembaban dan temperatur dengan tingkat kerusakan oleh A. hilaralis sebagaimana Tabel 4 dapat menjelaskan sebagian besar faktor-faktor kelembaban dan temperatur terhadap tingkat kerusakan. Pada HR Pantai
Cermin, tingkat kerusakan oleh A. hilaralis dipengaruhi oleh temperatur sebesar 16,9\% sedangkan pengaruh dari kelembaban adalah $18,7 \%$. Ketika kedua faktor tersebut dikombinasikan maka pengaruhnya terhadap tingkat kerusakan oleh $A$. hilaralis mencapai $18,7 \%$.

Tabel(Table) 4. Persamaan linear regresi dan koefisien determinan (R) tingkat serangan A. hilaralis dengan temperatur dan kelembaban (Equation of linear regression and coefficient of determination $(R)$ between severity level caused by A. hilaralis to humidity and temperature)

\begin{tabular}{|c|l|l|c|}
\hline \multirow{2}{*}{ No. } & \multicolumn{1}{|c|}{ Lokasi (Location) } & Persamaan regresi (Regression equation) & R (\%) \\
\hline 1. & HR Pantai Cermin (Pantai & $\mathrm{Y}=(-0,941)+0,112 \mathrm{X} 1$ & 16,9 \\
& Cermin Community forest) & $\mathrm{Y}=4,768-0,028 \mathrm{X} 2$ & 18,7 \\
& & $\mathrm{Y}=4,961-0,029 \mathrm{X} 1-0,004 \mathrm{X} 2$ & 18,7 \\
\hline 2. & HTI sektor Baserah $(H T I$ & $\mathrm{Y}=6,552-0,53 \mathrm{X} 1$ & 28,8 \\
& Baserah sector) & $\mathrm{Y}=3,608+0,018 \mathrm{X} 2$ & 30,3 \\
& & $\mathrm{Y}=4,418-0,015 \mathrm{X} 1+0,014 \mathrm{X} 2$ & 30,5 \\
\hline
\end{tabular}

Keterangan(Remarks): $\mathrm{X} 1$ : temperatur(temperature)

$\mathrm{X} 2$ : kelembaban (humidity)

$\mathrm{Y}$ : Tingkat kerusakan oleh serangan A. Hilaralis (severity level caused by A. hilaralis).

Pada HTI sektor Baserah, tingkat kerusakan oleh $A$. hilaralis dipengaruhi temperatur sebesar $28,8 \%$, sedangkan pengaruh dari kelembaban adalah 30,3\%. Ketika kedua faktor abiotik tersebut dikombinasikan maka akan meningkatkan pengaruhnya terhadap tingkat kerusakan oleh $A$. hilaralis mencapai $30,5 \%$. Nilai R $(18,7 \%$ di HR Pantai Cermin dan $30,5 \%$ di HTI sektor Baserah) memiliki arti masih terdapat faktor-faktor lain yang mempengaruhi tingkat kerusakan daun oleh A. hilaralis.

Pengaruh abiotik (temperatur dan kelembaban) yang rendah ini tidak dapat dijadikan sebagai alat estimasi terhadap tingkat kerusakan daun jabon yang disebabkan oleh A. hilaralis. Hal ini disebabkan masih banyak faktor-faktor abiotik lain yang mempengaruhi tingkat kerusakan tersebut. Menurut Sharma (1997), tingkat populasi dari serangga hama tidak dapat diestimasi hanya dengan temperatur dan kelembaban saja melainkan dengan kombinasi dari beberapa faktor abiotik lain.

Beberapa dugaan terhadap faktor ini adalah berupa faktor abiotik dan biotik. Dugaan faktor abiotik adalah perbedaan manajemen yang diterapkan oleh kedua lokasi tersebut. Pada HR
Pantai Cermin, pengelolaannya dilakukan lebih intensif dengan menerapkan pemupukan setiap 3 bulan, penyiraman, dan rutin dilakukan penyemprotan pestisida. Diduga, jabon pada lokasi ini memiliki tingkat pertumbuhan yang maksimal sesuai dengan potensi genetik yang dimilikinya sehingga pengaruh dari temperatur dan kelembaban lingkungan yang ekstrim dapat berkurang. Hal ini dapat dilihat pada Tabel 4 yang menyatakan bahwa pengaruh temperatur dan kelembaban hanya akan mempengaruhi sebesar $18,7 \%$. Sedangkan pada HTI sektor Baserah, hanya menerapkan pemeliharaan (pemupukan dan weeding) sampai pada umur 1 tahun saja. Diduga tidak dilakukan pemeliharaan, tegakan jabon mengalami tekanan oleh berbagai faktor, misalnya adalah kekurangan air dan nutrisi tanah sehingga turgoritasnya menurun dan lebih rentan terserang hama ini.

Faktor biotik yang diduga mempengaruhi perbedaan tersebut adalah struktur gulma yang berada di bawah tegakan jabon tersebut. Berdasarkan pengamatan di lapangan diperoleh informasi bahwa pada tegakan jabon di HTI Baserah baru saja dilakukan weeding, sehingga diduga kematian gulma tersebut akan meningkatkan intensitas serangan larva A. hilaralis. Hal 
ini berkaitan dengan keberadaan gulma sebagai inang beberapa serangga parasitoid, sehingga dengan hilangnya gulma-gulma tersebut akan mengurangi tekanan terhadap larva A. hilaralis.

\section{KESIMPULAN}

1. Pada HR Pantai Cermin, tingkat kerusakan daun oleh $A$. hilaralis menunjukkan korelasi negatif terhadap kelembaban $(0,187)$ dan positif terhadap temperatur $(0,169)$ sedangkan kombinasi dari temperatur dan kelembaban lingkungan memberikan pengaruh sebesar $18,7 \%$ terhadap tingkat kerusakan daun oleh $A$. hilaralis.

2. Pada HTI sektor Baserah, tingkat kerusakan daun oleh $A$. hilaralis menunjukkan korelasi positif terhadap kelembaban $(0,303)$ dan negatif terhadap temperatur $(-0,288)$, sedangkan kombinasi dari temperatur dan kelembaban lingkungan memberikan pengaruh sebesar $30,5 \%$ terhadap tingkat kerusakan daun oleh $A$. hilaralis.

\section{DAFTAR PUSTAKA}

Awmack, C.S., C.M. Woodcock and R. Harrington. 1997. Climate Change may Increase Vulnerability of Aphids to Natural Enemies. Ecological Entomology (22). page 366-368.

Bale, J.S. G.J. Masters, I.D. Hodkinson, C. Awmack, T.M. Bezemer, V.K. Brown, J. Butterfield, A. Buse, J.C. Coulson, J. Farrar, J.E.G. Good, R. Harrington, S. Hartley, T.H. Jones. R.L. Lindroth, M.C. Press, I. Symrnioudis, A.D. Watt, and J.B. Whittaker. 2002. Herbivory in Global Climate Change Research: Direct Effects of Rising Temperatures on Insect Herbivores. Global Change Biology $8: 1-16$.

Child, R.E. 2010. Insect Damage as a Function of Climate. http://www.natmus.dk. diakses 1 Februari 2010.
Horn, J.D. 2010. Temperature Synergism in Integrated Pest Management. http://cipm.ncsu.edu diakses 3 Februari 2010.

Kalshoven, I.G.E. 1981. Pests of Crops in Indonesia. PT Ichtiar Baru, Jakarta.

Kilmaskossu S.T.E.M and J. P. Nerokouw. 1993. Inventory of Forest Damage at Faperta Uncen Experiment Gardens in Manokwari Irian Jaya Indonesia. Proceedings of the Symphosium on Biotechnological and environmental Approaches to Forest and Disease Management. SEAMEO, Bogor.

Petzoldt, C. and A. Seaman. 2010. Climate Change Effect on Insect and Pathogens. http://www.climateandfarming.org. Pathogens. diakses 3 Februari 2010.

Salisbury, J.W. dan Ross. 1995. Fisiologi Tumbuhan. ITB, Bandung.

Sharma, D. G. 1997. Effect of Weather Parameter on Population Build up Key Pest of Maize. Bull. Insect Sci., page 120124.

Smith, R.F. 1997. Phisiology of Tree Resistance to Insect. Annual Review of Antomology (20): 75 - 91 .

Vazquez, C. C., I.V. Mendoza, M.R. Parra and Z.G. Vazquez. 2004. Influence of Temperature, Humidity and Rainfall on Field Population Trend of Stomoxys calcitrans (Diptera: Muscidae) in a Semiarid Climate in Mexico. Parasitol Latinoam (59). page 99 - 103.

Whiting, D., M. Roll. and L. Vickerman. 2010. Plant Growth Factor: Water. Colorado State University. http://cmg.colostate.edu. diakses 1 Februari 2010.

Wiyono, S. 2007. Perubahan Iklim dan Ledakan Hama dan Penyakit Tanaman. Makalah pada Keanekaragaman Hayati di tengah Perubahan Iklim: Tantangan Masa Depan Indonesia. KEHATI, Jakarta. 